\title{
閉ループ弾性体の形状計算アルゴリズム
}

\author{
高 須 亮 輔* 望 山洋*
}

\section{Shape Computation Algorithm for Closed Elastica}

\author{
Ryosuke Takasu* and Hiromi Mochiyama*
}

\begin{abstract}
In this paper, we propose a shape computation algorithm for quasi-static shape transition of a planar closed elastica which has a function as an impulse force generator utilizing a snap-through buckling of an elastic strip. The proposed algorithm has an advantage to compute the shape of the closed elastic more stably and quickly than the one to which the shooting method simply applied since it is based on mechanistic equations where an unstable computation factor has been eliminated. The proposed algorithm is written in the forms extensible to shape computation for spatial closed elastica. This good property is based on our modeling where a continuum elastic strip is approximated by a serial chain of multiple rigid links with elastic joints familiar with robotics. Effectiveness of the proposed algorithm is verified by shape transition simulation for planar closed elastica including snap-through buckling usually difficult to compute due to its instable nature. An example of shape transition simulation for spatial closed elastica is also shown for illustrating extension to 3-dimensional cases.
\end{abstract}

Key Words: Continuum Robot, Snap-through Buckling, Flexible Robot, Shape Computation, Simulation

\section{1.は じめに}

\section{1 研究背景と目的}

連続体ロボットは，剛体リンクや回転関節を持たない代わり に, 構造が弾性変形によって長さ方向に連続的に曲がり, 動物 の舌や触手のように滑らかな曲線を生成して動くロボットのク ラスである，と定義されている[1].この定義からも分かるよう に，連続体ロボットでは，その形状が曲線で表現される一次元 弾性体が利用されることが典型である，近年，連続体ロボット は, 能動カテーテルのような医療ロボットを中心として活発に 研究が行われている $[2] \sim[6]$.

筆者らは，連続体ロボットの一例として，帯状弾性体の飛び 移り座屈を利用した瞬発力発生機構を提案している [7] [8]. 飛び 移り座屈とは，たわませた弾性体（閉ループ弾性体）の端点を 駆動すると, 駆動角がある角度になった瞬間に逆形状へと急激 に変形する現象である。この機構を利用して小動物に匹敵する 俊敏性を有する手のひらサイズの小型走行ロボット [9]〜 [11] や. 高い旋回能力を有する遊泳ロボットを開発している [12]. しか し, 閉ループ弾性体に関する力学理論やシミュレーション手法が 不十分であるため, その機構の設計は試行錯誤的に行われてい るのが現状である。本研究の目的は, より良い設計パラメー夕 の探索に用いることのできる閉ループ弾性体の形状計算シミュ

原稿受付 2013 年 3 月 4 日

* 筑波大学大学院システム情報工学研究科知能機能システム専攻

${ }^{*}$ University of Tsukuba
レーション手法を構築することである.

\section{2 関連研究}

閉ループ弾性体，特にその飛び移り座屈の解析およびシミュ レーションに関する研究は, 非線形力学の分野で取り扱われて いる [13]〜 [18]. 閉ループ弾性体の静力学的平衡形状を求める問 題は，形状を表現する曲線パラメー夕に関する非線形常微分方 程式の 2 点境界值問題に帰着する。通常は, Shooting 法と呼ば れる初期値問題の繰り返し計算を行い, 数值的に解形状を求め る.しかし, 非線形力学分野で用いられているシミュレーショ ン手法には二つ問題がある. 第 1 に，二次元運動のみ扱われて いる場合がほとんどで，三次元への拡張の見通しが示されてい ないことである。第 2 に，二次元運動の場合でも，必ずしも安 定した形状計算シミュレーションを実行できないため，設計に 扔けるパラメー夕探索に利用しにくいことである，特に，筆者 らが対象とする瞬発力発生機構で扱うような, 弾性体の片端を 固定したまま，もう一端の固定角を変化させて飛び移り座屈付 近の現象を調べるシミュレーションにおいて, 単純な Shooting 法の適用では不安定あるいは収束が遅いことを筆者らは確認し ている。

\section{3 本研究の提案}

そこで本研究では, 飛び移り座屈のような不安定現象も含む, 閉ループ弾性体の準静的形状遷移をシミュレートするための形 状計算シミュレーションアルゴリズムを提案する，提案するア ルゴリズムは，数值計算を不安定にする変数が陽に現れないよ うに修正した力学式を利用することにより，単純なシューティ 
ング法と比べて, 様々なパラメータや拘束条件に対してより安 定かつ高速な形状遷移シミュレーションを実行するのに用いる ことができる。また， ロボットマニピュレータの運動学を利用 した連続体の多リンク近似により, 三次元運動のシミュレーショ ンへの拡張が可能となっている. 本稿では, 提案するアルゴリ ズムが様々なタイプの閉ループ弾性体を利用した瞬発力発生機 構のシミュレーションに用いることができることを示し，さら に，三次元シミュレーションへの拡張例を示す.

本研究で提案するアルゴリズムは, 閉ループ弾性体を有する 弾性体ロボットだけでなく, 一次元弾性体でモデル化される柔 軟物に対する力学計算にも広く利用できると期待される.

\section{4 本論文の構成}

本論文の構成は以下のとおりである，2 章では，これまでに開 発されてきた閉ループ弾性体の飛び移り座屈を利用した瞬発力 発生機構のいくつかを紹介したうえで, 弾性体の片端を固定し たままもう一端の固定角を変化させる形状遷移シミュレーショ ンを行うことの有用性を説明する. 3 章では, 平面型閉ループ弾 性体をばね関節を有する多リンク系で近似した離散モデルを示 す. 4 章では, 単純な Shooting 法を適用した場合のシミュレー ション手法の問題点を指摘したうえで, 提案するシミュレーショ ンアルゴリズムを説明する。閉ループ弾性体のいくつかの機構 に対する, 飛び移り座屈を含む形状遷移シミュレーション結果 も示す. 5 章では, 空間型閉ループ弾性体への拡張について説 明し，簡単なシミュレーション例を示す．最後の 6 章において, 本稿のまとめと今後の展望について述べる.

\section{2. 閉ループ弾性体の飛び移り座屈を利用した瞬発力発生 機構}

閉ループ弾性体の飛び移り座屈を利用した瞬発力発生機構は, たわませた弾性体の片端または両端にトルクを加え, 弾性体に 能動的に飛び移り座屈を生じさせることにより, シンプルな機 構でありながら瞬発力を得ることのできる機構である。端点の 拘束方法や, 弾性体の形状などにより, 様々なタイプが存在す る.これまで提案されてきた機構のタイプの一部を Table 1 に 示す.これら機構の詳細については, 文献 [21] を参照されたい.

この瞬発力発生機構の最も基本的なタイプは, 非駆動端点が フリージョイントとなっている自由端型である. 最も機構的に 単純なタイプは, 非駆動端点の終端姿勢がネジなどで固定され ている固定端型である。これら二つのタイプは非常に似ている が，形状遷移シミュレーションを実行する上で大きな差がある. 自由端型では非駆動端点のトルクは常に 0 であるが, 固定端型 では終端姿勢が決められているため非駆動端点に拘束トルクが 加わる.よって, この未知の拘束トルクを求める必要が生ずる. 形状遷移シミュレーションの際に, 単純な Shooting 法を適用し た場合，自由端型では問題は起きないが，固定端型では計算が 不安定または収束が遅いことが確認されている。すなわち，未 知の拘束トルクを計算するプロセスが, シミュレーションを不 安定化させていることになる。これらのタイプの他に, 両端を それぞれ逆向きに駆動させる両端駆動型や, 帯状弾性体と駆動 関節を剛体アームを介して結合するアーム型, さらには， 2 枚の 帯状弾性体を尖状になるようにつなぎ合わせ，直進性に特化し
Table 1 Typical types of impulse force generators based on snap-through buckling of closed elastica [21]

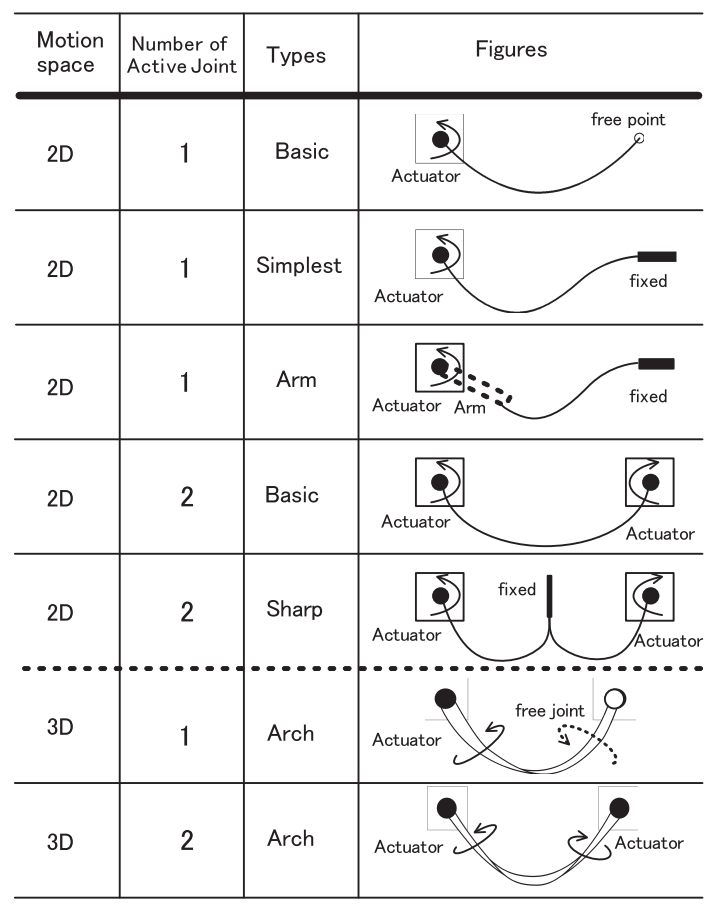

た尖状型があるが，これらの形状遷移シミュレーションにおい ても未知の拘束トルクの計算が必要となる。 さらに, 曲げだけ ではなくねじれも伴って三次元空間内を運動する閉ループ弾性 体のタイプも存在するが, 瞬発力発生機構として有用な構造と なるためには，未知の拘束トルクを考慮することが必要である.

すなわち，拘束トルクが生ずる閉ループ弾性体の形状遷移シ ミュレーションを首尾よく達成できると，空間型を含む様々な タイプの瞬発力発生機構の挙動を予測することが可能となる.

\section{3. 平面型閉ループ弾性体の離散モデル}

本稿では, 計算機でシミュレーションを行うために, 閉ルー プ弾性体をばね関節を有する多リンク系で離散化してモデル化 する。閉ループ弾性体の形状を表す連続曲線を, Fig. 1 に示す ように $n$ 本の折れ線により近似する. 各リンクとその節点に ベース側から手先に向かって順に 1 から $n$ まで番号をつける. $n$ を大きくすると, 多リンク系の運動学の式は, 曲線の形状を 表す式に漸近することが知られている $[19] . i+1$ 番めの節点の 位置べクトルを $\boldsymbol{p}_{i} \in R^{3}$ とすると, 次式で与えられる.

$$
\begin{gathered}
\boldsymbol{p}_{i}=\left[\begin{array}{c}
\sum_{h=1}^{i} l \cos \phi_{i} \\
\sum_{h=1}^{i} l \sin \phi_{i} \\
0
\end{array}\right] \\
\phi_{i}=\phi_{0}+\sum_{j=1}^{i} \theta_{j}
\end{gathered}
$$

ここで, $l$ はリンク長, $\phi_{i} \in R$ は $i$ 番めのリンクが $\mathrm{x}$ 軸とな す角 (絶対角), $\phi_{0} \in R$ はベースが $\mathrm{x}$ 軸となす角 (絶対角), 


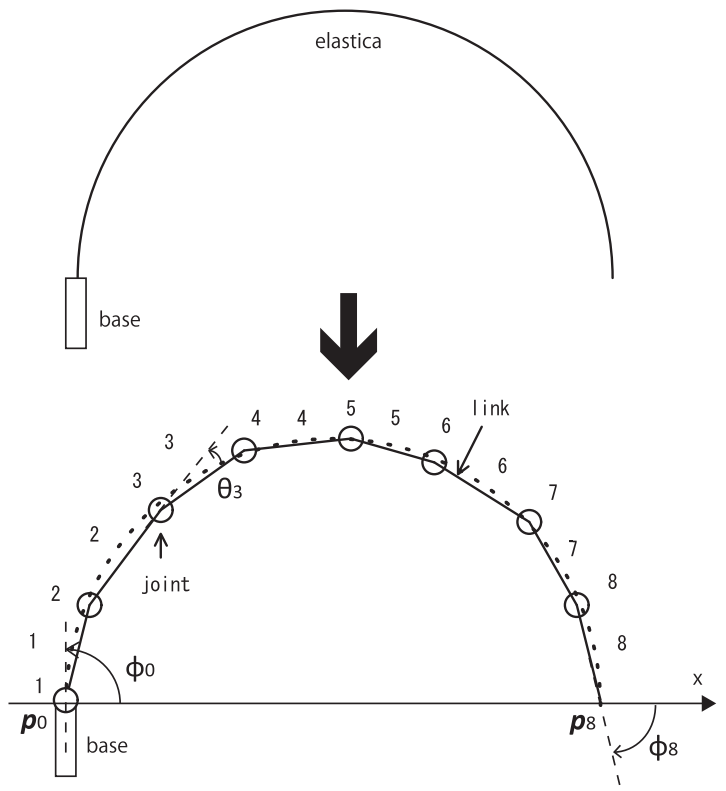

Fig. 1 Multi-link approximation of closed elastic $(n=8)$

$\theta_{i} \in R$ は $i$ 番めのリンクが $i-1$ 番めのリンクとなす角であ る.一般性を失うことなく, $\boldsymbol{p}_{0}=\mathbf{0}$ とする, 带状弾性体の端点 が $d$ 離れた位置に拘束されているとすると, 弾性体の先端位置 $\boldsymbol{p}_{n}$ は，以下の条件を満たす必要がある。

$$
\boldsymbol{p}_{n}=d \boldsymbol{e}_{\mathrm{x}}
$$

ここで, $e$ は下添え字の軸方向の単位ベクトルを表す。ささらに, 固定端型の場合は，近似折れ線の先端の向き $\phi_{n}$ も拘束される ため, 次式も考慮する必要がある.

$$
\phi_{n}=\phi_{\text {end }}
$$

帯状弾性体の形状を離散化したときの各関節まわりのトルクの 釣り合いを表現する方程式は次式で与えられる.

$$
k_{d} \theta_{i}=\boldsymbol{e}_{\mathrm{z}}^{T}\left\{\left(\boldsymbol{p}_{n}-\boldsymbol{p}_{i-1}\right) \times \boldsymbol{\lambda}\right\}+\tau
$$

ここで, $i=1,2, \cdots, n$ であり,$k_{d}$ は離散ばね定数である。 ま た, $\lambda \in R^{3}$ は帯状弾性体の先端にかかる拘束力を, $\tau \in R$ は 帯状弾性体の先端にかかる拘束トルクを意味する。離散ばね定 数の同定に関しては，文献 [22] を参照されたい.

\section{4. 平面型閉ループ弾性体の準静的形状計算シミュレーショ ンアルゴリズム}

本章では，まず Shooting 法を単純に適用した場合のアルゴ リズムを示し，その問題点を指摘した上で，本研究で提案する 形状計算アルゴリズムを示す。また，提案アルゴリズムを用い た形状遷移シミュレーション結果を示す。

\subsection{Shooting 法の単純適用における問題点}

Shooting 法の単純適用アルゴリズムは, 以下のとおりである. ベースの絶対角 $\phi_{0}$ が与えられている下で, まず前準備とし て, $\theta_{1}, \theta_{2}, \cdots, \theta_{n}$ の組, さらには, 拘束力 $\boldsymbol{\lambda}$, 拘束トルク $\tau$ を仮決めする。次に, 式（3）も利用しつつ式（5）を漸化的に
用いて， $\theta_{1}, \theta_{2}, \cdots, \theta_{n}$ を計算すると同時に, 式 (1) と式 (2) を漸化的に用いて, $\boldsymbol{p}_{1}, \cdots, \boldsymbol{p}_{n}$ を計算し, 形状を求める。 こ こで, 手先位置 $\boldsymbol{p}_{n}$ が拘束位置 $d \boldsymbol{e}_{\mathrm{x}}$ から閾值 $\epsilon_{p}$ 以上離孔てい る場合, 拘束力 $\boldsymbol{\lambda}$ に $\boldsymbol{p}_{n}$ と $d \boldsymbol{e}_{\mathrm{x}}$ の差分に係数を掛けた值を加 えて更新する. また, 手先角度 $\phi_{n}$ が固定角度 $\phi_{\text {end }}$ から閾値 $\epsilon_{\phi}$ 以上離孔ている場合, 拘束トルク $\tau$ に先端の絶対角度 $\phi_{n}$ と 固定角度 $\phi_{\mathrm{end}}$ の差分に係数を掛けた值を加えて更新する。な お, 自由端の場合は, 常に $\tau=0$ として $\boldsymbol{\lambda}$ のみ更新する.

上記プロセスを先端の位置拉よび向きの誤差が指定された範 囲内に収束するまで繰り返すことにより，与えられたべース絶 対角 $\phi_{0}$ に対する閉ループ弾性体の形状と拘束力, 拘束トルク が得られる。しかし，この単純アルゴリズムでは，自由端の場 合は問題ないが, 拘束トルクの計算を必要とする固定端の場合 はシミュレーションが不安定または収束が非常に遅くなること が確認されている.

\section{2 提案アルゴリズム}

$\tau$ の計算が不安定要因と考えられるため, 式 $(5)$ から $\tau$ を 消去した式を用いることが，提案アルゴリズムの基本的なアイ デアである. $i$ 番めと 1 番めの方程式の差分を取り変形すると, 次式が得られる。

$$
k_{d} \theta_{i}=-\boldsymbol{e}_{\mathrm{z}}^{T}\left(\boldsymbol{p}_{i-1} \times \boldsymbol{\lambda}\right)+k_{d} \theta_{1}
$$

ただし，この式では $i=2,3, \cdots, n$ である.

提案アルゴリズムは，以下のと㧍りである.

ベースの絶対角 $\phi_{0}$ が与えられている下で，まず前準備とし て, 第 1 関節角 $\theta_{1}$ と拘束力 $\boldsymbol{\lambda}$ を仮決めし, さらに式 (1) か ら $\boldsymbol{p}_{1}$ を求めておく. 次に, 仮決めした值から, 式 (5) を漸化 的に用いて, $\theta_{2}, \cdots, \theta_{n}$ を計算すると同時に, 式 (1) と式 (2) を漸化的に用いて, $\boldsymbol{p}_{2}, \cdots, \boldsymbol{p}_{n}$ を計算し, 形状を求める。ここ で, 手先位置 $\boldsymbol{p}_{n}$ が拘束位置 $d \boldsymbol{e}_{\mathrm{x}}$ から閾值 $\epsilon_{p}$ 以上離れている 場合, 拘束力 $\boldsymbol{\lambda}$ に $\boldsymbol{p}_{n}$ と $d \boldsymbol{e}_{\mathrm{x}}$ の差分に係数を掛けた值を加え て更新し，仮形状を決定する。ここで，仮形状と述べているの は, 角度に関する先端拘束 $\phi_{n}=\phi_{\text {end }}$ が満たされていない可能 性があるからである. $\phi_{n}$ が $\phi_{\text {end }}$ から闇值 $\epsilon_{\phi}$ 以上離れている 場合は, 先端の絶対角度 $\phi_{n}$ と固定角度 $\phi_{\text {end }}$ の差分に係数を 掛けた值を利用してベースの関節角 $\theta_{1}$ の更新を行い, 改めて 形状を求める。 ここで, このアルゴリズムでは, 更新パラメー 夕が $\tau$ からべースの関節角 $\theta_{1}$ に変更されていることに注意さ れたい.

上記プロセスを, 先端の位置抢よび向きの誤差が指定された 範囲内に収束するまで繰り返すことにより, 与えられたベース 絶対角 $\phi_{0}$ に対する閉ループ弾性体の形状と拘束力が得られる. この $\phi_{0}$ に適当な角度刻み幅 $\Delta s t e p$ を足して更新することによ り，形状遷移の様子を見ることができる。この提案アルゴリズ ムを用いた形状遷移計算の手順を, Algorithm 1 にまとめる.

\section{3 シミュレーション結果}

提案アルゴリズムを用いて, 閉ループ弾性体の準静的形状 遷移シミュレーションを行う. 長さ $L=140[\mathrm{~mm}]$, ばね倸 数 $k_{d}=0.646[\mathrm{Nm} / \mathrm{rad}]$ の帯状弾性体を使用し, 軸間距離 $d=100[\mathrm{~mm}]$, 分割数 $n=30$ とする. この手法でベース

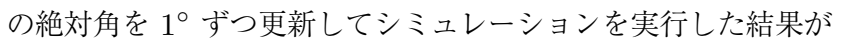




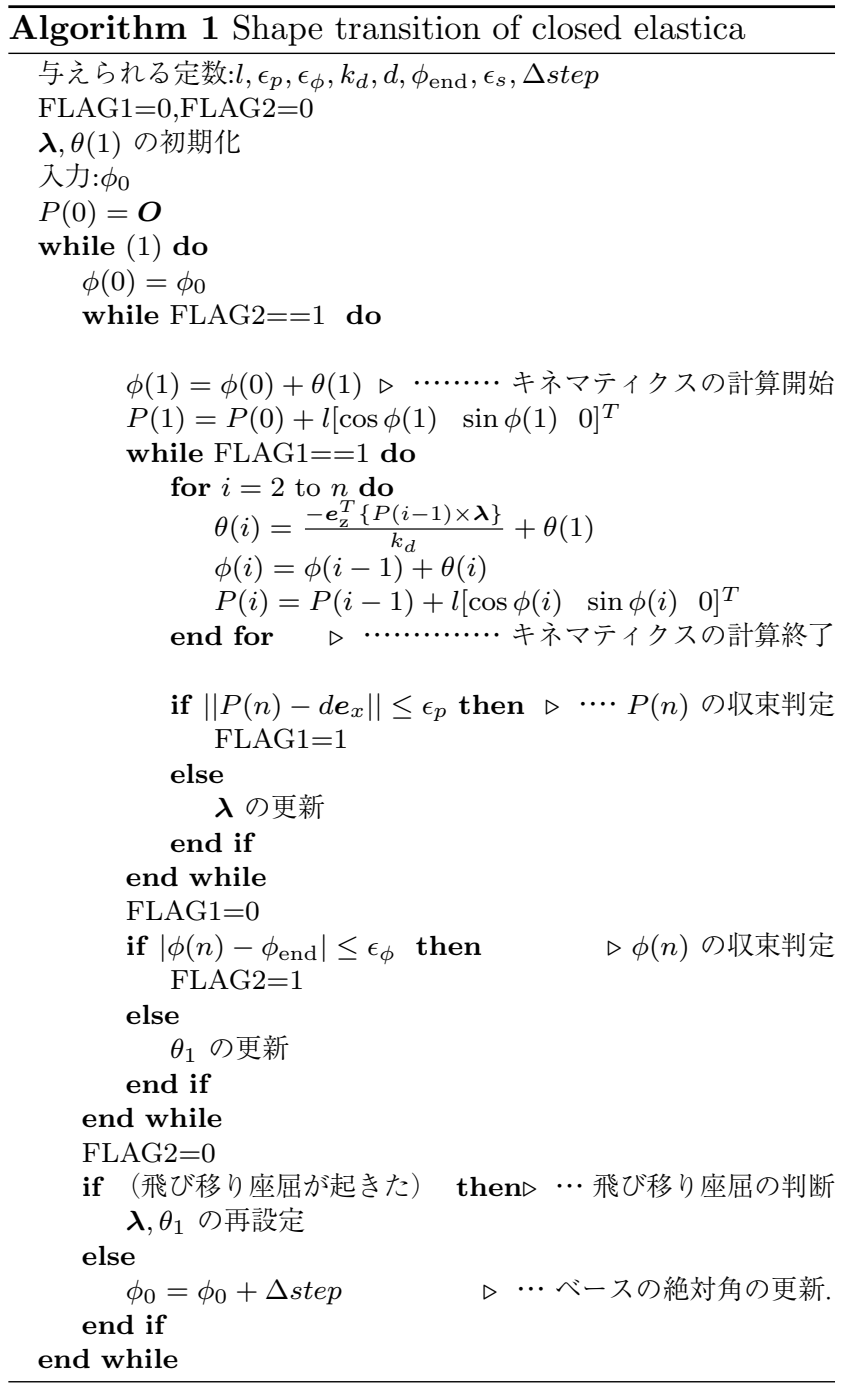

Fig. 2〜Fig. 4 である. Fig. 2 と Fig. 3 はそれぞれ $\phi_{\mathrm{end}}=0^{\circ}$ と $\phi_{\text {end }}=40^{\circ}$ の固定端型のシミュレーションの結果である. これらの図では, 実線が閉ループ弾性体のベースを反時計回り に駆動させた場合の形状を描いており, 破線が時計回りに駆動 させた場合の形状を描いている. Fig. 4 は両端駆動型のシミュ レーション結果である。両端駆動型の場合は, 変化する $\phi_{0} に$ 対して, $\phi_{\text {end }}=-\phi_{0}$ とするため, 固定端の場合と同様に拘束 トルクの計算が必要となる。この図では, 実線が左側の端点を 反時計回りに駆動させた場合の形状を描いており，破線が左側 の端点を時計回りに駆動させた場合の形状を描いている。これ らの図はそれぞれ $10^{\circ} こ ゙ と に$ 形状が移り変わる様子を示してい る.これらの図より, 固定端の場合でも, 飛び移り座屈を含む 形状遷移の様子を確認することができる.

\section{4 考察}

・提案アルゴリズムによるシミュレーションでは, ほとんど すべてのパラメータに対して, ベースの絶対角の刻み幅を $1^{\circ}$ ずつ更新しても問題が起きないが, Shooting 法単純適 用アルゴリズムの場合は， $0.1^{\circ}$ の更新角ステップでも， シ ミュレーションが収束に至らない場合がある。

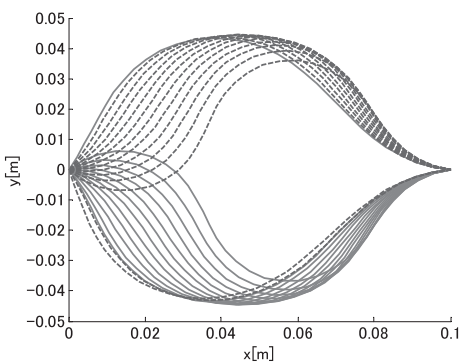

Fig. 2 Shape transition of close elastica for fixed angle $\phi_{\text {end }}=$ $0^{\circ}$

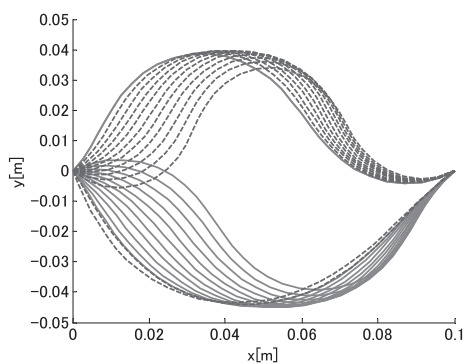

Fig. 3 Shape transition of close elastica for fixed angle $\phi_{\mathrm{end}}=$ $40^{\circ}$

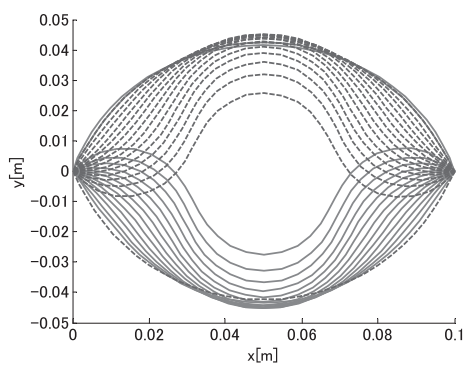

Fig. 4 Shape transition of close elastica for double active type

- Table 1 に示した他の種類の平面型閉ループ弾性体に対し ても，この提案アルゴリズムが適用可能であることを確認 している.

・元の連続体の式を離散化したことにより，本シミュレーショ ンは非線形方程式を解くことに相当するが，良く知られて いる Newton-Raphson 法を援用する場合, 飛び移り座屈 地点の近くでは, 解くべき非線形方程式を特徵づける非線 形関数の Jacobi 行列が特異となるため注意が必要である。 本シミュレーションでは, この Jacobi 行列の行列式を計算 することで, 飛び移り座屈の地点までの近さを計算し，行 列式が十分小さくなったところで飛び移り座屈が発生した とみなし，シミュレーションの破綻を防いでいる [23]. 形 状遷移シミュレーションを頑健に実行するためには，この ような飛び移り座屈地点における配慮が必要である.

\section{5. 空間型への拡張}

本章では，前章で示した平面型形状計算の手法を，三次元運 動を行う空間型へと拡張する。

\section{1 空間型閉ループ弾性体の離散モデル}

空間型閉ループ弾性体においても，まず 3 章の離散モデルと 


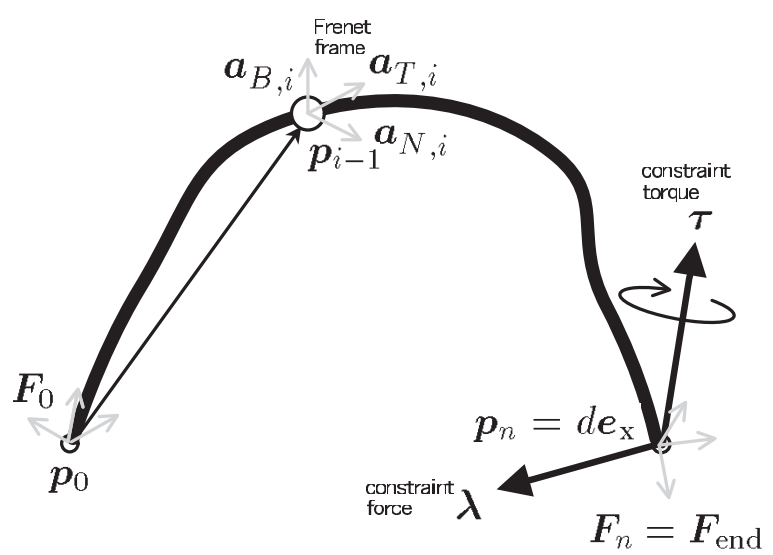

Fig. 5 Torque balance for spatial closed elastica

同様に連続曲線を $n$ 本のリンクで近似し，各関節に関節角に比 例したトルクが生じるばね関節を設ける. 第 $i$ リンクに固定さ れた座標系の姿勢行列を $\boldsymbol{F}_{i}=\left[\boldsymbol{a}_{T, i} \boldsymbol{a}_{N, i} \boldsymbol{a}_{B, i}\right]$ とする. ここ で, $\boldsymbol{a}_{T, i}, \boldsymbol{a}_{N, i}, \boldsymbol{a}_{B, i} \in R^{3}$ はそれぞれ第 $i$ リンクに固定された 座標系の $\mathrm{x}$ 軸, $\mathrm{y}$ 軸, $\mathrm{z}$ 軸の正方向を向いた単位べクトルを示 しており, 帯状弾性体の長さ方向に $\mathrm{x}$ 軸, 幅方向に $\mathrm{z}$ 軸を取り, 右手系の座標系を取る。このとき, $i-1$ 番めと $i$ 番めの姿勢 行列の関係は回転行列を用いて次のように表すことができる.

$$
\boldsymbol{F}_{i}=\boldsymbol{F}_{i-1} \boldsymbol{R}_{\mathrm{x}}\left(\theta_{T, i}\right) \boldsymbol{R}_{\mathrm{y}}\left(\theta_{N, i}\right) \boldsymbol{R}_{\mathrm{z}}\left(\theta_{B, i}\right)
$$

ここで， $\boldsymbol{R}$ は下添え字軸まわりの回転行列を示しており， $\theta_{T, i}$, $\theta_{N, i}, \theta_{B, i}$ はそれぞれ張られた座標系の $\mathrm{x}$ 軸, $\mathrm{y}$ 軸, $\mathrm{z}$ 軸まわ りの関節角を表している。 また, $i$ 番めの関節は $i-1$ 番めの 関節の $\boldsymbol{a}_{T, i}$ の向きに $l$ だけ離れた位置にあるため,

$$
\boldsymbol{p}_{i}=\boldsymbol{p}_{i-1}+l \boldsymbol{F}_{i} \boldsymbol{e}_{\mathrm{x}}
$$

が成り立つ、さらに，仮想仕事の原理より，次のような各軸まわ りのトルクの釣り合いを表す方程式が得られる（Fig. 5）[24].

$$
\begin{aligned}
& k_{T d} \theta_{T, i}=\boldsymbol{a}_{T, i}^{T}\left\{\left(\boldsymbol{p}_{n}-\boldsymbol{p}_{i-1}\right) \times \boldsymbol{\lambda}+\boldsymbol{\tau}\right\} \\
& k_{N d} \theta_{N, i}=\boldsymbol{a}_{N, i}^{T}\left\{\left(\boldsymbol{p}_{n}-\boldsymbol{p}_{i-1}\right) \times \boldsymbol{\lambda}+\boldsymbol{\tau}\right\} \\
& k_{B d} \theta_{B, i}=\boldsymbol{a}_{B, i}^{T}\left\{\left(\boldsymbol{p}_{n}-\boldsymbol{p}_{i-1}\right) \times \boldsymbol{\lambda}+\boldsymbol{\tau}\right\}
\end{aligned}
$$

ここで, $k_{T d}, k_{N d}, k_{B d}$ はそれぞれ各軸まわりの関節角に対 する離散ばね定数を表しており， $\tau \in R^{3}$ は先端にかかる拘束 トルクを表している。なお，帯状弾性体の場合は $k_{N d} \gg 1$ の ため $\theta_{N, i} \approx 0$ となることに注意されたい.

\section{2 拘束条件}

空間型の場合, 拘束条件が変わるため, その変化をこの節で まとめる.

位置に関する拘束条件は平面のときに述べた式（3）と同じで ある。

終端姿勢を決定する拘束条件は, 以下の三つの型のいずれか に対応させて選ぶ必要がある.

- 0 軸固定型

これは端点のフレームが特に拘束されておらず, 終端がピン

ジョイントとなっている場合である. この場合, 常に $\boldsymbol{\tau}=\mathbf{0}$ である。
- 1 軸固定型

これは終端の接線方向の軸（ $\mathrm{x}$ 軸）まわりのみ回転可能な 場合である。この状況は三次元空間特有である。この場合, 終端の座標系の $\mathrm{x}$ 軸が

$$
\boldsymbol{F}_{n} \boldsymbol{e}_{\mathrm{x}}=\boldsymbol{F}_{\text {end }} \boldsymbol{e}_{\mathrm{x}}
$$

となるように拘束されている。 なお， $\boldsymbol{F}_{\text {end }}$ は決められた 終端の座標系の姿勢を表す行列である。

- 全軸固定型

これは終端リンクの姿勢 $\boldsymbol{F}_{n}$ が固定される場合であり, 次 式で表現できる.

$$
\boldsymbol{F}_{n}=\boldsymbol{F}_{\text {end }}
$$

\section{3 空間型閉ループ弾性体の形状計算アルゴリズム} 空間型閉ループ弾性体の形状計算アルゴリズムは，以下のと おりである。

平面の時の $\phi_{0}$ に対応するベースフレーム $\boldsymbol{F}_{0}$ が与えられて いる下で，まず前準備として，拘束力 $\boldsymbol{\lambda}$ と拘束トルク $\boldsymbol{\tau}$ を仮 決めしておく. 次に, 式 $(9)$ 式 $(11)$ を漸化的に用いて, $\boldsymbol{\theta}_{1}$, $\boldsymbol{\theta}_{2}, \cdots, \boldsymbol{\theta}_{n}$ を計算すると同時に, 式 (7) と（8）を漸化的に 用いて, $\boldsymbol{p}_{1}, \cdots, \boldsymbol{p}_{n}$ を計算し, 形状を求める。 なおここで, $\boldsymbol{\theta}_{i}=\left[\theta_{T, i} \theta_{N, i} \theta_{B, i}\right]^{T}$ である。 ここで, $\boldsymbol{p}_{n}$ が $d \boldsymbol{e}_{\mathrm{x}}$ から閾值 $\epsilon_{p}$ 以上離れている場合, 拘束力 $\boldsymbol{\lambda}$ に $\boldsymbol{p}_{n}$ と $d \boldsymbol{e}_{\mathrm{x}}$ の差分に係数 を掛けた值を加えて更新し, 仮形状を求める。 その後, 仮形状 は拘束条件を満たすとは限らないため, 拘束トルク $\boldsymbol{\tau}$ の更新を 行う. 拘束トルクの更新は終端の姿勢に基づいて行われる。計 算で求められた終端姿勢 $\boldsymbol{F}_{n}$ と設定した終端姿勢 $\boldsymbol{F}_{\text {end }}$ にずれ がある場合,

$$
\boldsymbol{F}_{n} \boldsymbol{R}(\boldsymbol{\omega}, \alpha)=\boldsymbol{F}_{\text {end }}
$$

を満たすような $\boldsymbol{\omega}, \alpha$ の組み合わせが存在し, それらを求める ことができる $[20]$. ここで, $\boldsymbol{R}(\boldsymbol{\omega}, \alpha)$ はある単位ベクトル $\boldsymbol{\omega} ま$ わりに $\alpha$ 回転させる回転作用行列であり, この式は $\boldsymbol{F}_{n}$ をべ クトル $\boldsymbol{\omega}$ まわりに $\alpha$ 回転させると, 終端姿勢 $\boldsymbol{F}_{\text {end }}$ に一致す ることを意味している．よって， $\alpha$ が閾值 $\epsilon_{F}$ 以上の場合， $\alpha \boldsymbol{\omega}$ に比例定数をかけたべクトルを $\tau$ に加えて更新を行い, 改めて 形状を求める.

上記プロセスを, 先端の位置および向きの誤差が指定された 範囲内に収束するまで繰り返すことにより，与えられたベース フレーム $\boldsymbol{F}_{0}$ に対する閉ループ弾性体の形状と拘束力, 拘束卜 ルクが得られる， $\boldsymbol{F}_{0}$ を更新することにより，始点の座標系の 変化に応じた形状遷移の様子を見ることができる。この空間型 閉ループ弾性体の形状計算アルゴリズムを用いた形状遷移計算 の手順を，Algorithm 2 にまとめる.

\section{4 シミュレーション結果}

たわませた帯状弾性体の両端を，長さ方向の軸に沿ってとも

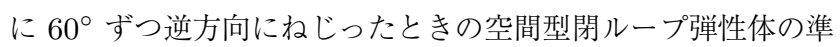
静的形状遷移シミュレーションを行う。この場合の拘束条件は, 全軸固定に相当する. 具体的には, ベースフレームおよび目標 終端姿勢を 


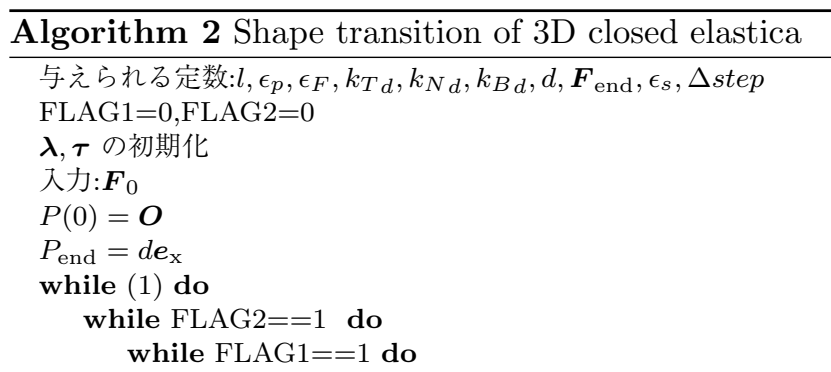

for $i=1$ to $n$ do $\quad \triangleright \cdots$ *ネマティクスの計算開始 $\theta_{T}(i)=\frac{\boldsymbol{a}_{T}^{T}(i)\left\{\left(P_{\text {end }}-P(i-1)\right) \times \boldsymbol{\lambda}+\boldsymbol{\tau}\right\}}{k_{T d}}$

$\theta_{N}(i)=\frac{\boldsymbol{a}_{N}^{T}(i)\left\{\left(P_{\text {end }}-P(i-1)\right) \times \boldsymbol{\lambda}+\boldsymbol{\tau}\right\}}{k_{N d}}$

$\theta_{B}(i)=\frac{\boldsymbol{a}_{B}^{T}(i)\left\{\left(P_{\mathrm{end}}-P(i-1)\right) \times \boldsymbol{\lambda}+\boldsymbol{\tau}\right\}}{k_{B d}}$

$\boldsymbol{F}(i)=\boldsymbol{F}(i-1) \boldsymbol{R}_{\mathrm{x}}\left(\theta_{T}(i)\right) \boldsymbol{R}_{\mathrm{y}}\left(\theta_{N}(i)\right) \boldsymbol{R}_{\mathrm{z}}\left(\theta_{B}(i)\right)$

$P(i)=P(i-1)+l \boldsymbol{F}(i) \boldsymbol{e}_{\mathrm{x}}$

end for $\quad \triangleright \cdots \cdots$ キネマティクスの計算終了

if $\left\|P(n)-P_{\text {end }}\right\| \leq \epsilon_{p}$ then $\triangleright \cdots P(n)$ の収束判定 FLAG1 $=1$

else

$\lambda$ の更新

end if

end while

FLAG1 $=0$

$\boldsymbol{R}(\boldsymbol{\omega}, \alpha)=\boldsymbol{F}_{n}^{T} \boldsymbol{F}_{\text {end }}$

$\boldsymbol{\omega}, \alpha$ を算出

if $|\alpha| \leq \epsilon_{F}$ then

$\triangleright \cdots \cdots \cdots$ の収束判定

else

FLAG2 $=1$

$\tau$ の更新

end if

end while

FLAG2 $=0$

if (飛び移り座屈が起きた) then $\cdots$ 飛び移り座屈の判断 $\boldsymbol{\lambda}, \boldsymbol{\tau}$ の再設定

else

$$
\boldsymbol{F}_{0}=\boldsymbol{F}_{0} \Delta \boldsymbol{F}_{0}
$$

end if

end while

$$
\begin{aligned}
\boldsymbol{F}_{0} & =\boldsymbol{R}_{z}\left(\phi_{0_{b}}\right) \boldsymbol{R}_{\mathrm{x}}\left(\phi_{0_{t}}\right) \\
\boldsymbol{F}_{\text {end }} & =\boldsymbol{R}_{\mathbf{z}}\left(-\phi_{0_{b}}\right) \boldsymbol{R}_{\mathrm{x}}\left(\phi_{0_{t}}\right)
\end{aligned}
$$

と規定した上で， $\phi_{0_{b}}=60^{\circ}$ に固定し， $\phi_{0_{t}}$ を変化させる，長 さ $L=140[\mathrm{~mm}]$, ばね係数 $k_{B d}=0.646[\mathrm{Nm} / \mathrm{rad}]$ の帯状弾 性体を使用し, 軸間距離 $d=100[\mathrm{~mm}]$, 分割数 $n=30$ とす る. ばね係数 $k_{T d}, k_{N d}$ については同定実験を行っていないた め, $k_{T d}=0.215[\mathrm{Nm} / \mathrm{rad}], \quad k_{N_{d}}=10,000[\mathrm{Nm} / \mathrm{rad}]$ と仮定 する．Fig. 6 は閉ループ弾性体の形状を真上から見た図と斜め から見た図であり，両端をともに $60^{\circ}$ ずつ逆方向にねじった結 果である。この図の破線部分が带状弾性体の中心線を, 実線部 分はその辺を表している。この図から，ねじれた帯状弾性体の 様子が確認できる.

\section{5 考察}

• 0 軸固定, 1 軸固定の場合は, 拘束トルク $\boldsymbol{\tau}$ を更新パラメー 夕にしても形状遷移シミュレーションに問題が起きないこ とから, 空間型の 0 軸固定, 1 軸固定は, 平面自由端型に
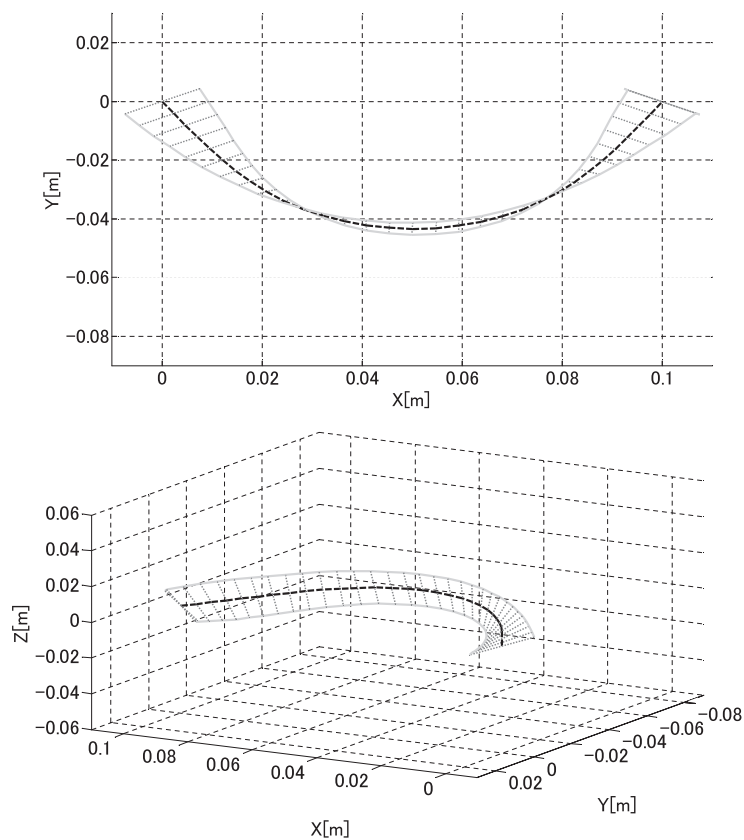

Fig. 6 Simulation result for spatial closed elastica. (The upper figure is the top view while the lower one is the view from an angle)

相当すると予想される.

・前節で示したシミュレーションの範囲では問題が起こらな いが, 全軸固定の場合は拘束トルク $\tau$ を更新パラメータに すると形状遷移シミュレーションが不安定または収束が非 常に遅くなることを確認している。したがって，空間型の 全軸固定は，平面固定端型に相当すると考えられる，平面 型と同様に，不安定な拘束トルクが現れないアルゴリズム により, 状況が改善される可能性がある.

なお，空間型のシミュレーションについては，今後よりよい アルゴリズムを考案するとともに, パラメータをいろいろと変 化させて，適用範囲を調べる予定である.

\section{6. おわりに}

\section{1 本研究の成果}

-平面型閉ループ弾性体に対して, 非駆動端点が固定され，拘 束トルクの計算が必要となる固定端型の場合でも，安定し て形状遷移を計算できるアルゴリズムを提案した，提案ア ルゴリズムは Shooting 法を基礎としており，様々なタイ プの閉ループ弾性体の形状計算に適用可能である.

・提案アルゴリズムは, 空間型閉ループ弾性体に対しても拡 張可能な形で定式化してあり, 空間型閉ループ弾性体のシ ミュレーション例を示した

\section{2 今後の展望}

実験によるモデルの妥当性の検証や同定法の確立は, 今後の もっとも重要な課題の一つである. 空間型のシミュレーション に関しては，座屈を伴わない簡単な形状遷移のシミュレーショ ン例を示したにとどまっており, 空間型閉ループ弾性体の設計 のために, 適用可能な条件やアルゴリズムの改良など, 今後さ らなる検討を行っていく必要がある。 


\section{参 考 文 献}

[1] G. Robinson and J. Davies: "Continuum robots-a state of the art," Proc. IEEE International Conference on Robotics and Automation, vol.4, pp.2849-2854, 1999.

[ 2 ] R.J. Webster, J.M. Romano and N.J. Cowan: "Mechanics of Precurved-Tube Continuum Robots," IEEE Trans. Robotics, vol.25, no.1, pp.67-78, 2009.

[ 3 ] D.B. Camarillo, C.R. Carlson and J.K. Salisbury: "Configuration Tracking for Continuum Manipulators with Coupled Tendon Drive," IEEE Trans. Robotics, vol.25, no.4, pp.798-808, 2009.

[4] N. Simaan, K. Xu, W. Wei, A. Kapoor, P. Kazanzides, P. Flint and R. Taylor: "Design and Integration of a Telerobotic System for Minimally Invasive Surgery of the Throat," International Journal of Robotics Research (Special Issue on Medical Robotics), vol.28, no.9, pp.1134-1153, 2009.

[5] M. Mahvash and P.E. Dupont: "Stiffness Control of Surgical Continuum Manipulaors," IEEE Trans. Robotics, vol.27, no.2, pp.334-345, 2011.

[6] A. Bajo, R.E. Goldman, L. Wang, D. Fowler and N. Simaan: "Integration and Preliminary Evaluation of an Insertable Robotic Effectors Platform for Single Port Access Surgery," Proc. of 2012 IEEE International Conference on Robotics and Automation, pp.3381-3387, 2012.

[7] H. Mochiyama, M. Watari and H. Fujimoto: "A Robotic Catapult based on the Closed Elastica and Its Application to Robotic Tasks," Proc. of the 2007 IEEE/RSJ International Conference on Intelligent Robots and Systems (IROS07), pp.1508-1513, 2007.

[ 8 ] A. Yamada, H. Mochiyama and H. Fujimoto: "Kinematics and Statics of Robotic Catapults based on the Closed Elastica," Proc. of the 2007 IEEE/RSJ International Conference on Intelligent Robots and Systems (IROS07), pp.3993-3998, 2007.

[9] T. Tsuda, H. Mochiyama and H. Fujimoto: "A Compact Kick-and-Bounce Mobile Robot powered by Unidirectional Impulse Force Generators," Proc. of the 2009 IEEE/RSJ International Conference on Intelligent Robots and Systems (IROS09), pp.3416-3421, 2009.

[10] T. Tsuda, H. Mochiyama and H. Fujimoto: "Robotic Jerboa: A Compact Bipedal Kick-and-Slide Robot powered by Unidirectional Impulse Force Generators," Proc. of the 2010 IEEE/RSJ International Conference on Intelligent Robots and Systems (IROS10), pp.2523-2524, 2010.

[11] A. Yamada, H. Mameda, H. Mochiyama and H. Fujimoto:
"A Compact Jumping Robot utilizing Snap-through Buckling with Bend and Twist," Proc. of the 2010 IEEE/RSJ International Conference on Intelligent Robots and Systems (IROS10), pp.389-394, 2010.

[12] S. Imai and H. Mochiyama: "Basic Performance of Flat Kickswimming Robot Powered by Impulse Force Generator with Spatially-deformable V-shape Elastica," Proc. of the 15th International Conference on Climbing and Walking Robots and the Support Technologies for Mobile Machines (CLAWAR 2012), pp.297-304, 2012.

[13] V.G.A. Goss, G.H.M. van der Heijden, J.M.T. Thompson and S. Neukirch: "Experiments on Snap Buckling, Hysteresis and Loop Formation in Twisted Rods," Experimental Mechanics, vol.45, no.2, pp.101-111, 2005.

[14] J.S. Chen and Y.Z. Lin: "Snapping of a Planar Elastica with Fixed End Slopes," ASME Journal of Applied Mechanics, vol.75, no.4, 041024(1/6), 2008.

[15] J.S. Chen and S.Y. Hung: "Snapping of an Elastica under Various Loading Mechanisms," European Journal of Mechanics A/Solids, vol.30, pp.525-531, 2011.

[16] V. Denoël and E. Detournay: "Eulerian formulation of Constrained Elastica," International Journal of Solids and Structures, vol.48, pp.625-638, 2011.

[17] J.S. Chen and H.H. Wu: "Deformation and Stability of an Elastica under a Point Force and Constrainted by a Flat Surface," International Journal of Mechanical Science, vol.53, pp.42-50, 2011.

[18] J.S. Chen and W.Z. Lin: "Dynamic Snapping of a Suddenly Loaded Elastica with Fixed End Slopes," International Journal of Non-Linear Mechanics, vol.47, pp.489-495, 2012.

[19] H. Mochiyama: "Kinematics for the Whole Arm of a Serialchain Manipulator," Advanced Robotics, vol.15, no.2, pp.255$275,2001$.

[20] R.M. Murray, Z. Li and S. Sastry: A Mathematical Introduction to Robotic Manipulation. CRC Press, 1994.

[21] 望山洋, 山田篤史, 藤本英雄: “閉ループ弾性体による瞬発力発生機 構”, 日本ロボット学会誌, vol.29, no.6, pp.492-495, 2011.

[22] 木下文, 望山洋： “1 次元弾性体の弾性係数の同定法”, 第 28 回日本 ロボット学会学術講演会, AC1D1-3, 2010 .

[23] 高須亮輔, 望山洋：“閉ループ弾性体を用いた瞬発力発生機構の形状 遷移モデリング”, 第 12 回計測自動制御学会システムインテグレー ション部門講演会 (SI2011), pp.0233-0236, 2011.

[24] 山田篤史, 望山洋, 藤本英雄 : “閉ループ柔軟カタパルトの静力学解 析”, 日本ロボット学会誌, vol.26, no.2, pp.169-177, 2008.

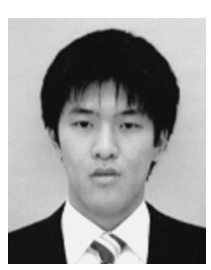

高須亮輔（Ryosuke Takasu）

2011 年筑波大学理工学群工学システム学類卒業. 2013 年同大学大学院システム情報工学研究科知能 機能システム専攻博士前期課程修了. 同年東芝三菱 電機産業システム株式会社入社，現在に至る。

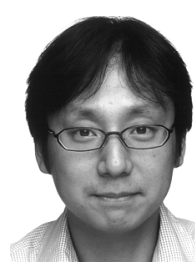

望山 洋 (Hiromi Mochiyama)

1993 年早稲田大学理工学部電気工学科卒業. 1995 年同大学理工学研究科修士課程電気工学専攻修了. 1998 年北陸先端科学技術大学院大学情報科学研究 科博士後期課程修了. 同年同大学助手. 1999 年防 衛大学校機械工学教室助手. 2000 年同校機械シス テム工学科講師. 2003 年名古屋工業大学機械工学 科卜ヨ夕自動車寄附講座助教授. 2007 年筑波大学大学院システム情 報工学研究科准教授, 現在に至る. 柔軟ロボット学の研究に従事. 計 測自動制御学会, 日本機械学会, IEEE 会員. 博士 (情報科学).

(日本ロボット学会正会員) 